\title{
High termite richness in an urban fragment of Atlantic Forest in northeastern Brazil
}

\author{
Matilde Vasconcelos Ernesto ${ }^{1,3}$, Elaine Folly Ramos ${ }^{1}$, Flávia Maria da Silva Moura ${ }^{2}$ \& \\ Alexandre Vasconcellos ${ }^{3,4}$ \\ ${ }^{1}$ Centro de Ciências Aplicadas e Educação, Universidade Federal da Paraíba, 58297-000, Rio Tinto, PB, \\ Brazil.e-mail: matildeernesto@gmail.come-mail: elafolly@yahoo.com.br \\ ${ }^{2}$ Unidade Acadêmica de Ciências Biológicas, Centro de Saúde e Tecnologia Rural, Universidade Federal de \\ Campina Grande, 58708-110, Patos, PB, Brazil.e-mail: fmsmoura@yahoo.com.br \\ ${ }^{3}$ Laboratório de Termitologia, Departamento de Sistemática e Ecologia, Centro de Ciências Exatas e da \\ Natureza, Universidade Federal da Paraíba, 58051-900, João Pessoa, PB, Brazil. \\ e-mail: avasconcellos@dse.ufpb.br \\ ${ }^{4}$ Corresponding author: Alexandre Vasconcellos, e-mail: avasconcellos@dse.ufpb.br
}

ERNESTO, M.V., RAMOS, E.F., MOURA, F.M.S., VASCONCELLOS, A. High termite richness in an urban fragment of Atlantic Forest in northeastern Brazil. Biota Neotropica. 14(3): e20140052. http://dx.doi. org/10.1590/1676-06032014005214

\begin{abstract}
Termites are very abundant in tropical ecosystems and have active roles in nutrient cycling and soil formation, but few studies of their assemblages have been undertaken in the Brazilian Atlantic Forest. The present study analyzed the composition of termite assemblages in a fragment of Atlantic Forest embedded within an urban matrix in northeastern Brazil. Five standardized sampling protocols of termites were applied, with a total sampling effort of $1500 \mathrm{~m}^{2}$. We encountered 45 species of termites belonging to 25 genera and three families. The soil-feeders group demonstrated the greatest species richness, while wood-feeders species were the most abundant. The species richness of termite in the study area was the greatest yet recorded for an Atlantic forest site in Brazil, indicating the importance of urban fragments for conserving tropical biodiversity.
\end{abstract}

Keywords: Isoptera, Feeding Groups, Biodiversity, Neotropical Region.

ERNESTO, M.V., RAMOS, E.F., MOURA, F.M.S., VASCONCELLOS, A. Alta riqueza de térmitas em um fragmento urbano de Floresta Atlântica do Nordeste Brasileiro. Biota Neotropica. 14(3): e20140052. dx. doi.org/10.1590/1676-06032014005214

Resumo: Térmitas são muito abundantes em ecossistemas tropicais e possuem papéis ativos na ciclagem de nutrientes e formação do solo, mas poucos estudos sobre suas taxocenoses têm sido realizados na Floresta Atlântica. O presente estudo analisou a composição das taxocenoses de térmitas em um fragmento de Floresta Atlântica inserida dentro de uma matriz urbana no Nordeste do Brasil. Cinco protocolos padronizados de amostragem de térmitas foram aplicados, o que totalizou um esforço amostral de $1500 \mathrm{~m}^{2}$. Foram encontradas 45 espécies de térmitas pertencentes a 25 gêneros e três famílias. O grupo alimentar dos humívoros demonstrou a maior riqueza de espécies, enquanto as espécies xilófagas foram as mais abundantes. A riqueza de espécies de térmitas na área de estudo foi a maior registrada até o momento para uma área de Floresta Atlântica no Brasil, indicando a importância dos fragmentos urbanos para a conservação da biodiversidade tropical.

Palavras-chave: Isoptera, Grupo alimentar, Biodiversidade, Região Neotropical.

\section{Introduction}

The Atlantic Forest is one of the principal humid forests in South America. It is isolated from the Amazonian and Andean forests by a corridor of open and semi-open vegetation formations including Caatinga (dryland), Cerrado (neotropical savanna), and Chaco (arid lowland savanna) (Costa 2003, Pennington et al. 2006). More than 500 years of anthropogenic disturbances have caused the Atlantic Forest to lose more than $88.3 \%$ of its original cover (Ribeiro et al. 2009). Currently, the
Atlantic Forest is considered one of the priority areas for global biodiversity conservation (Myers et al. 2000).

Termites are eusocial insects that have important roles in ecosystem functioning by influencing the processes of nutrient cycling and altering the physical and chemical structures of the soil (Lee \& Wood 1971, Wood \& Sands 1978, Holt \& Lepage 2000). More than 2,900 living species have been described globally (Krishna et al. 2013), and the greatest values of $\alpha$ diversity and biomass have been recorded in humid tropical forests (Vasconcellos 2010, Jones \& Eggleton 2011). Up to 50\% 
of the decomposition of organic detritus of plant origin has been attributed to termite action in these forests (Bignell \& Eggleton 2000).

In spite of the importance of termites to tropical and subtropical ecosystems, our knowledge of their diversity and functional roles in their respective ecosystems are still relatively scarce. Very few studies have been published concerning the structure of termite assemblages in northeastern Brazil, especially in the Caatinga and Atlantic Forest ecosystems (Bandeira et al. 1998, Bandeira et al. 2003, Mélo \& Bandeira 2004, Vasconcellos 2010, Vasconcellos et al. 2010). Furthermore, although some studies have been performed in fragments of Atlantic Forest in Brazil, including the study area of this work, the species richness of termites was clearly underestimated. Studies of termite assemblages are considered basic prerequisites for understanding the important functions of these insects in the ecosystem, and for identifying their patterns of diversity and endemism. The present study therefore sought to describe the composition of termite assemblages in a fragment of Atlantic Forest embedded within an urban matrix in northeastern Brazil with regard to their species richness, numbers of encounters, and feeding groups.

\section{Materials and methods}

\section{Study sites}

The present study was undertaken in the Mata do Buraquinho Permanent Protection Area (PPA) (07 $08^{\circ} 42^{\prime}$ 'S x $\left.34^{\circ} 51^{\prime} 54^{\prime \prime} \mathrm{W}\right)$ located within the urban perimeter of the municipality of João Pessoa, Paraíba State, Brazil. The PPA occupies an area of 515 ha of a slightly rolling landscape, with altitudes varying from 35 to $85 \mathrm{~m}$. The topsoilis sandy redyellow podzol, and the climate there is hot and humid (classified as "As" in the Köppen [1936] system), with rainfall principally from March to August (Barbosa 2008). The average annual temperature and humidity are $27^{\circ} \mathrm{C}$ and $80 \%$, respectively, and the mean annual rainfall is $1,482 \mathrm{~mm}$ (Governo do Estado da Paraíba 1985). The regional vegetation is characterized as Seasonal Semideciduous Forest (IBGE 1992), and this area is considered one of the largest and most important remnants of that domain in Paraíba State (Barbosa 2008; Oliveira \& Melo 2009).

\section{Sampling protocols}

The termite assemblages were inventoried in December/ 2010 and from May through November/2012 using standard protocols for rapid evaluations of termite diversity. Each protocol was performed by establishing six $65 \mathrm{~m} \times 2 \mathrm{~m}$ transects within forest areas without any apparent human impacts, at minimum distances of $50 \mathrm{~m}$ from the forest borders and from other transects. Five $5 \mathrm{~m}$ x $2 \mathrm{~m}$ plots were established $10 \mathrm{~m}$ one from the other in each transect, totaling 30 plots $\left(300 \mathrm{~m}^{2}\right)$ per protocol. The sampling effort in each plot was 1person-hour. During this period, the termites were searched in active and abandoned nests (up to $2 \mathrm{~m}$ above ground level), in tunnels and live and dead tree trunks, in the leaf litter and the interiors of fallen branches, in the soil (at depths up to $15 \mathrm{~cm}$ ), under rocks, and in dead roots. The specimens collected were stored in labeled glass vials containing 75\% alcohol and were subsequently deposited in the Isopteran collection of the Federal University of Paraíba.

\section{Feeding groups}

Based on in situ observations of feeding and on information available in the literature concerning Neotropical termites (DeSouza \& Brown 1994, Constantino 1999, Bandeira et al. 2003, Sena et al. 2003, Vasconcellos et al. 2005, Vasconcellos 2010), the species were classified as belonging to the following feeding groups: (i) wood-feeders, that consume the wood of live or dead trees in various stages of decomposition; (ii) soilfeeders, that feed on humus and generally live in the ground; (iii) wood/soil feeders, that consume humus as well as wood in different stages of decomposition, and usually carrying soil into the wood they are consuming; and (iv) wood/leaf feeders, that consume both wood in advanced stages of decomposition and leaf litter on the forest floor.

\section{Analyses}

Species accumulation curve was prepared using the Mao Tau method considering the $95 \%$, confidence intervals for 1,000 randomizations without replacement the original data. These analyses were performed using Estimate S9.1.0 software (Colwell 2013).

\section{Results}

Forty-five species of termites (624 encounters), belonging to 25 genera and three families were recorded in the Mata do Buraquinho Permanent Preservation Area (Table 1). The family Termitidae was the best-represented in terms of the numbers of species $(40 ; 88.9 \%)$, followed by Kalotermitidae ( 3 ; $6.7 \%)$ and Rhinotermitidae $(2 ; 4.4 \%)$. The Termitidae were also dominant in terms of the frequencies of encounters $(86.1 \%)$. In relation to subfamilies, Termitinae and Nasutitermitinae were the most representative in terms of the numbers of species (12; $30 \%$, each) and Termitinae in terms of the frequencies of encounters $(34.5 \%)$. The soil-feeders group was dominant in terms of the number of species $(19 ; 42.2 \%)$ and the woodfeeders group in terms of the frequency of encounters $(41.2 \%)$.

The species that constructed conspicuous nests in the area were: Anoplotermes banksi Emerson, 1925, Embiratermes neotenicus (Holmgren, 1906), Labiotermes labralis (Holmgren, 1906), Microcerotermes indistinctus Mathews, 1977, M. strunckii (Sörensen, 1884), Nasutitermes corniger (Motschulsky, 1855), N. ephratae (Holmgren, 1910), N. macrocephalus (Silvestri, 1903), N. obscurus Holmgren, 1906, and Silvestritermes holmgreni (Snyder, 1926).

The species accumulation curve in the Mata do Buraquinho PPA is almost stabilized (Figure 1). The upper confidence level was 46.84 species and the lower 43.16 , very close to the actual number observed in the field (45 spp.).

\section{Discussion}

Forty-five species were encountered in the Mata do Buraquinho PPA, of which 31 could be identified to the species level. Including four new records of this study (Ibitermes inflatus, Orthognathotermes longilamina, O. tubesauassu e Termes hispaniolae), a total of 46 species are now known from the Atlantic Forest (Bandeira et al. 1998, Brandão 1998, Vasconcellos et al. 2005, Reis \& Cancello 2007, Vasconcellos 2010, Souza et al. 2012). Considering only the region north of the São Francisco River, 37 species have been identified to the species level. Studies examining termite assemblages in the 
Termites in an urban fragment of Atlantic Forest

Table 1. Termite species found in the Mata do Buraquinho Permanent Preservation Area in an Atlantic Forest fragment in northeastern Brazil. W, wood; S, subterranean; L, litter; A, arboreal; E, epigeal; I, inquiline.

\begin{tabular}{|c|c|c|c|}
\hline Species & Number of encounters & Place of sampling & Feeding group \\
\hline \multicolumn{4}{|l|}{ KALOTERMITIDAE } \\
\hline Calcaritermes rioensis Krishna, 1962 & 8 & $\mathrm{~W}$ & Wood \\
\hline Neotermes sp. & 1 & $\mathrm{~W}$ & Wood \\
\hline Rugitermes sp. & 3 & $\mathrm{~W}$ & Wood \\
\hline \multicolumn{4}{|l|}{ RHINOTERMITIDAE } \\
\hline Coptotermes testaceus (Linnaeus, 1758) & 19 & $\mathrm{~S}$ & Wood \\
\hline Heterotermes longiceps (Snyder, 1924) & 56 & $\mathrm{~S}$ & Wood \\
\hline \multicolumn{4}{|l|}{ TERMITIDAE } \\
\hline \multicolumn{4}{|l|}{ APICOTERMITINAE } \\
\hline Apicotermitinae sp. 1 & 4 & $\mathrm{~S}$ & Soil \\
\hline Apicotermitinae sp. 2 & 6 & $\mathrm{~S}$ & Soil \\
\hline Apicotermitinae sp. 3 & 19 & $\mathrm{~S}$ & Soil \\
\hline Apicotermitinae sp. 4 & 6 & $\mathrm{~S}$ & Soil \\
\hline Apicotermitinae sp. 5 & 3 & $\mathrm{~S}$ & Soil \\
\hline Anoplotermes banksi Emerson, 1925 & 19 & A & Soil \\
\hline Anoplotermes sp. 1 & 6 & $\mathrm{~S}$ & Soil \\
\hline Anoplotermes sp. 2 & 25 & $\mathrm{~W} / \mathrm{S}$ & Soil \\
\hline Anoplotermes sp. 3 & 11 & $\mathrm{~W} / \mathrm{S}$ & Soil \\
\hline Anoplotermes sp. 4 & 18 & $\mathrm{~S}$ & Soil \\
\hline Ruptitermes sp. & 4 & $\mathrm{~L}$ & Wood/Leaf \\
\hline \multicolumn{4}{|l|}{ NASUTITERMitinaE } \\
\hline Atlantitermes sp. & 2 & $\mathrm{~W}$ & Wood/Soil \\
\hline Convexitermes sp. & 1 & $\mathrm{~W}$ & Wood/ Soil \\
\hline Diversitermes diversimiles (Silvestri, 1901) & 4 & $\mathrm{~L}$ & Wood/Leaf \\
\hline Nasutitermes callimorphus Mathews, 1977 & 24 & $\mathrm{~W}$ & Wood \\
\hline Nasutitermes corniger (Motschulsky, 1855) & 15 & A & Wood \\
\hline Nasutitermes ephratae (Holmgren, 1910) & 16 & A & Wood \\
\hline Nasutitermes gaigei Emerson, 1925 & 25 & $\mathrm{~W}$ & Wood \\
\hline Nasutitermes jaraguae (Holmgren, 1910) & 11 & $\mathrm{~W}$ & Wood \\
\hline Nasutitermes macrocephalus (Silvestri, 1903) & 3 & A & Wood \\
\hline Nasutitermes obscurus Holmgren, 1906 & 3 & A & Wood \\
\hline Subulitermes microsoma (Silvestri, 1903) & 3 & $\mathrm{~S} / \mathrm{I}$ & Soil \\
\hline Velocitermes velox (Holmgren, 1906) & 2 & $\mathrm{~L}$ & Wood/Leaf \\
\hline \multicolumn{4}{|l|}{ SYNTERMITINAE } \\
\hline Embiratermes neotenicus (Holmgren, 1906) & 13 & $\mathrm{E}$ & Wood/ Soil \\
\hline Embiratermes parvirostris Constantino, 1992 & 55 & $\mathrm{~S}$ & Soil \\
\hline Ibitermes inflatus Vasconcellos, 2002 & 2 & $\mathrm{~S}$ & Soil \\
\hline Labiotermes labralis (Holmgren, 1906) & 19 & A & Soil \\
\hline Silvestritermes holmgreni (Snyder, 1926) & 33 & A & Wood/Soil \\
\hline \multicolumn{4}{|l|}{ Termitinae } \\
\hline Amitermes amifer Silvestri, 1901 & 54 & $\mathrm{~W}$ & Wood/Soil \\
\hline Cavitermes tuberosus (Emerson, 1925) & 7 & I & Soil \\
\hline Cylindrotermes sapiranga Rocha \& Cancello, 2007 & 27 & $\mathrm{~W}$ & Wood \\
\hline Dentispicotermes conjunctus Araujo, 1969 & 1 & $\mathrm{~S}$ & Soil \\
\hline Microcerotermes indistinctus Mathews, 1977 & 41 & A & Wood \\
\hline Microcerotermes strunckii (Sörensen, 1884) & 5 & A & Wood \\
\hline Neocapritermes opacus Hagen, 1858 & 5 & $\mathrm{~S}$ & Wood/Soil \\
\hline Neocapritermes talpoides Krishna \& Araujo, 1968 & 14 & $\mathrm{~S}$ & Soil \\
\hline Orthognathotermes longilamina Rocha \& Cancello, 2009 & 2 & $\mathrm{~S} / \mathrm{I}$ & Soil \\
\hline Orthognathotermes tubesauassu Rocha \& Cancello, 2009 & 7 & $\mathrm{~S} / \mathrm{I}$ & Soil \\
\hline Termes hispaniolae (Banks, 1918) & 2 & $\mathrm{~W} / \mathrm{I}$ & Wood/Soil \\
\hline Termes medioculatus Emerson in Snyder, 1949 & 20 & $\mathrm{~W} / \mathrm{I}$ & Wood/Soil \\
\hline Total of species & 45 & & \\
\hline Total of encounters & 624 & & \\
\hline
\end{tabular}




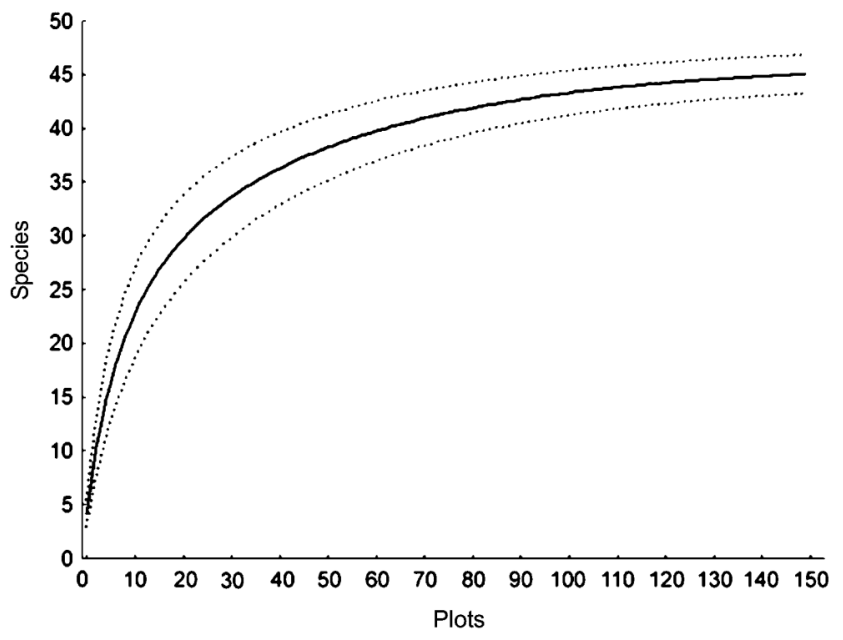

Figure 1. Termite species accumulation curves and $95 \%$ confidence intervals for an urban fragment of Atlantic Forest in northeastern Brazil.

Atlantic Forest have reported between 21\% and 100\% nondetermined species (Bandeira et al.1998, Silva \& Bandeira 1999, Brandão 1998, Vasconcellos et al. 2005, Reis \& Cancello 2007, Vasconcellos 2010, Souza et al. 2012). The sampling effort used in this study was the highest ever made in a Brazilian Atlantic Forest fragment, which could partly explain the high species richness in relation to other studies in the same biome.

The termite fauna of the Mata do Buraquinho PPA has been previously investigated using various methodologies (Bandeira et al. 1998, Silva \& Bandeira 1999, Vasconcellos 2010). The number of species collected in the present study (45 spp.) was greater than in any previous publication. In these earlier works, only $0 \%$ to $12 \%$ of the insects were identified to the species level (Bandeira et al. 1998, Silva \& Bandeira 1999). More recently, Vasconcellos (2010) evaluated the biomass and abundance of termites and reported 29 species in the PPA.

The number of species of termites in the Mata do Buraquinho PPA was greater than reports from other Atlantic Forest fragments, where richness varied from 11 to 38 species (Bandeira et al. 1998, Silva \& Bandeira 1999, Brandão 1998, Vasconcellos et al. 2005, Reis \& Cancello 2007, Vasconcellos 2010, Souza et al. 2012). In terms of other Brazilian morphoclimatic domains, the number of species encountered here was within the amplitude reported for areas of Cerrado vegetation (30 to 70 species) (Constantino 2005) and for the Amazon region (11 to 88 species) (Bandeira \& Macambira 1988, Bandeira 1989, Constantino 1992, De Souza \& Brown 1994), but higher than the amplitude reported for Caatinga areas (10 to 26 species) (Mélo \& Bandeira 2004, Vasconcellos et al. 2010, Alves et al. 2011).

Equal numbers of species were found in the present study for the subfamilies Nasutitermitinae and Termitinae, with the Termitinae being more abundant. Other studies examining the termite fauna in Atlantic Forest areas have reported the subfamily Nasutitermitinae as dominant in terms of the numbers of species and relative abundance (Bandeira et al. 1998, Brandão 1998, Vasconcellos et al. 2005, Reis \& Cancello 2007, Vasconcellos 2010, Souza et al. 2012). The low abundance observed for the family Kalotermitidae probably underestimates their true numbers, as most of the colonies of this termite group are quite small and form inside pieces of dried wood or in the canopies of trees, making their collection much more difficult when using rapid survey collection techniques (Roisin et al. 2006, Reis \& Cancello 2007).

The soil-feeders group demonstrated the largest number of species - a pattern different from that observed in other studies conducted in the Atlantic Forest, where the wood-feeders group was responsible for from $39 \%$ to $64 \%$ of the total species richness (Bandeira et al. 1998, Brandão 1998, Vasconcellos et al. 2005, Reis \& Cancello 2007, Souza et al. 2012). This fact is certainly associated with the huge sampling effort, which increases the sampling of rare soil-feeders species. In terms of abundance, on the other hand, the wood-feeders group dominated in the Mata do Buraquinho PPA. High species richness is therefore not always directly linked to high abundance and high biomasses in this ecosystem (Souza et al. 2012).

Approximately $35 \%$ of all termite species in humid tropical forests in South America construct conspicuous nests (Constantino 1992, Martius 1994, Bandeira \& Vasconcellos 2002). All of the 10 species of termites known to construct conspicuous nests in Atlantic Forest sites north of the São Francisco River were encountered in the Mata do Buraquinho PPA, including $N$. obscurus, which was identified in previous studies as Nasutitermes sp. (Vasconcellos et al. 2005, Vasconcellos et al. 2008, Vasconcellos 2010, Souza et al. 2012). Vasconcellos (2010) reported nine species that constructed arboricolous nests in a previous study undertaken in the Mata do Buraquinho PPA. Additionally, the present study encountered a single species (E. neotenicus) that constructed epigeous nests.

The Mata do Buraquinho PPA contained an expressive number of termite species for an Atlantic Forest fragment embedded within an urban matrix. The effective conservation of many species will depend on their capacity to persist in fragmented habitats in the midst of modified landscapes (Holland \& Bennett 2011). Extreme urbanization almost always reduces the species richness of vertebrates, invertebrates, and plants, although in cases of moderate urbanization these effects vary among the different taxonomic groups (Mckinney 2008). Brown (1997) reported that under conditions of low environmental disturbance termite species richness may even increase. The high diversity of the termite fauna in the Mata do Buraquinho PPA reinforces the importance of small forest fragments in conserving the biodiversity of the Atlantic Forest - even when these remnants sites are embedded within an urban matrix.

\section{Acknowledgments}

The authors would like to thank the directors of the Benjamin Maranhão Botanical Garden (located in the Mata do Buraquinho PPA) for their permission to undertake the termite collections; Reginaldo Constantino for the identification of some species; A Adriano M. Souza, Aline O. Lopes, Ana C.F. Alves, Carolina N. Liberal, Daniel D. Bó, Dayse P. Nascimento, Everton P. Lorenzo, Giácomo R.P. Monteiro, Gindomar G. Santana, José R.C. Barbosa, Luiz P.A. Silva, Ricardo A. Nink, Rozzanna E.C.R. Figueirêdo, Virgínia F.P. Araújo, and Wellington E. Santos for their help with the fieldwork; and CAPES for the Masters grant and financial support awarded to Matilde Vasconcelos Ernesto. 


\section{References}

Alves, W.F., Mota, A.S., Lima, R.A.A., Bellezoni, R. \& Vasconcellos, A. 2011. Termites as Bioindicators of Habitat Quality in the Caatinga, Brazil: Is There Agreement Between Structural Habitat Variables and the Sampled Assemblages? Neotrop. Entomol. 40(1):39-46, http://dx.doi.org/10.1590/S1519-566X2011000100006

Bandeira, A.G. \& Macambira, M.L.J. 1988. Térmitas de Carajás, Estado do Pará, Brasil: composição faunística, distribuição e hábito alimentar. Bol. Mus. Para. Emílio Goeldi, Zool. 4(2): 175-190.

Bandeira, A.G. \& Vasconcellos, A. 2002. A quantitative survey of termites in a gradient of disturbed highland forest in Northeastern Brazil (Isoptera). Sociobiology 39:429-439.

Bandeira, A.G. 1989. Análise da termitofauna (Insecta:Isoptera) de uma floresta primária e de uma pastagem na Amazônia Oriental. Bol. Mus. Para. Emílio Goeldi, Zool. 5:225-241.

Bandeira, A.G., Pereira, J.C.D., Miranda, C.S. \& Medeiros, L.G.S. 1998. Composição da fauna de cupins (Insecta, Isoptera) em área de Mata Atlântica em João Pessoa, Paraíba, Brasil. Rev. Nordestina Biol. 12(1/2):9-17.

Bandeira, A.G., Vasconcellos, A., Silva, M.P. \& Constantino, R. 2003. Effects of habitat disturbance on the termite fauna in a highland humid forest in the Caatinga domain, Brazil. Sociobiology 42(1):117-127.

Barbosa, M.R.V. 2008.Floristic composition of a remnant of Atlantic Coastal Forest in João Pessoa, Paraíba, Bazil. In The Atlantic Coastal Forest of Northeastern Brazil (W.W. Thomas \& E.G. Briton, eds). New York Botanical Garden Press, New York, p.439457.

Bignell, D.E. \& Eggleton, P. 2000. Termites in ecosystems. In Termites: Evolution, Sociality, Symbiosis, Ecology (T. Abe, D.E. Bignell \& M. Higashi, eds.). Kluwer Academic Publications, Dordrecht, p.363-387.

Brandão, D. 1998. Patterns of termite (Isoptera) diversity in the Reserve Florestal de Linhares, state of Espírito Santo, Brazil. Rev. Bras. Entomol. 41:151-153.

Brown JR., K.S. 1997. Diversity, disturbance, and sustainable use of Neotropical forests: insects as indicators for conservation monitoring. J. Insect. Conserv. 1:25-42, http://dx.doi.org/10.1023/A:1018422807610

Colwell, R.K. 2013. EstimateS: Statistical estimation of species richness and shared species from samples, Version 9.1.0. http://viceroy.eeb. uconn.edu/estimates/ (ultimo acesso em 15/08/2013).

Constantino, R. 1992. Abundance and diversity of termites (Insecta: Isoptera) in two sites of primary rain forest in Brazilian Amazonia. Biotropica 24(3):420-430.

Constantino, R. 1999. Chave ilustrada para identificação dos gêneros de cupins (Insecta: Isoptera) que ocorrem no Brasil. Pap. Avulsos Zool. (São Paulo) 40, 387-448.

Constantino, R. 2005. Padrões de diversidade e endemismo de térmitas no bioma Cerrado. In Biodiversidade, Ecologia e Conservação do Cerrado (A.O. Scariot, J.C.S. Silva \& J.M. Felfili, eds.). Ministério do MeioAmbiente, Brasília, p.319-333.

de Souza O.F.F, \& Brown, V.K. 1994. Effects of habitat fragmentation on Amazonian termite communities.J. Trop. Ecol. 10:197206.

Governo do Estado da Paraíba. 1985. Atlas Geográfico do Estado da Paraíba. Grafset, João Pessoa.

Holland, G.J. \& Bennett, A.F. 2011.Recolonization of forest fragments by a native rodent following experimental "extinctions". Austral Ecol. 36:521-529, http://dx.doi.org/10.1111/j.1442-9993.2010.02182.x

Holt, J.A. \& Lepage, M. 2000.Termites and soil properties. In Termites: Evolution, Sociality, Symbiosis, Ecology (T. Abe, D.E. Bignell \& M. Higashi, eds.). Kluwer Academic Publications, Dordrecht, p.389-407.

IBGE. Anuário estatístico do Brasil. 1992. 52 ed. Fundação Instituto Brasileiro de Geografia e Estatística, Rio de Janeiro.
Jones, D.T. \& Eggleton, P. 2011. Global Biogeography of Termites: A Compilation of Sources. In Biology of Termites: A Modern Synthesis (D.E. Bignell, Y. Roisin \& N. Lo, eds.). Springer SBM, Dordrecht, p.477-498.

Köppen, W. 1936. Das geographische system der klimate. In Handbuch der Klimatologie, part C. (W. Köppen\& R. Geiger, eds.). Verlag von Gebrüder Borntraeger, Berlin, p.1-44.

Krishna, K., Grimaldi, D.A., Krishna, V. \& Engel, M.S. 2013. Treatise on the Isoptera of the world. B. Am. Mus. Nat. Hist. 377:1-2704, http://dx.doi.org/10.1206/377.1

Lee, K.E. \& Wood, T.G. 1971. Termites and soils. Academic Press, London and New York.

Martius, C. 1994. Diversity and ecology of termites in Amazonian forest. Pedobiology 38: 407-428.

Mckinney, M.L. 2008. Effects of urbanization on species richness: A review of plants and animals. Urban Ecosyst 11: 161-176.

Mélo, A.C.S. \& Bandeira, A.G. 2004. A qualitative and quantitative survey of termites (Isoptera) in an open shrubby Caatinga in Northeast Brazil. Sociobiology 44(3):707-716.

Myers, N., Mittermeier, R.A., Mittermeier, C.G., Fonseca, G.A.B. \& Kent, J. 2000.Biodiversity hotspots for conservation priorities. Nature 403:853-858.

Oliveira, S.C.C. \& Melo, R.S. 2009. As trilhas do Jardim Botânico Benjamim Maranhão (João Pessoa - PB) como recurso para interpretação ambiental. Cad. Virtual Tur. 9(2):113-125.

Pennington, R.T., Lewis, G.P. \& Ratter, J.A. 2006. An overview of the plant diversity, biogeography and conservation of neotropical savannas and seasonally dry forests. In Neotropical savannas and dry forests: Plant diversity, biogeography, and conservation. (R.T. Pennington, G.P. Lewis, \& J.A. Ratter, eds.). Taylor \& Francis CRC Press, Oxford, p.1-29.

Reis, Y.T. \& Cancello, E.M. 2007. Riqueza e diversidade de cupins (Insecta, Isoptera) numa área de mata primária e outra secundária, na Mata Atlântica do sudeste da Bahia. Iheringia, Zool. 97:229234.

Ribeiro, M.C., Metzger, j.p., Martensen, A.C., Ponzoni, F.J. \& Hirota, M.M. 2009. The Brazilian Atlantic Forest: How much is left, and how is the remaining forest distributed? Implications for conservation. Biol. Conserv. 142:1141-1153, http://dx.doi.org/10.1016/j.biocon. 2009.02.021

Roisin, Y., Dejean, A., Corbara, B., Orivel, J., Samaniego, M. \& Leponce, M. 2006. Vertical stratification of the termite assemblage in a Neotropical rainforest. Oecologia 149:301-311.

Sena, J.M., Vasconcellos, A., Gusmão, M.A.B. \& Bandeira, A.G. 2003. Assemblage of termites in a fragment of cerrado on the coast of Paraiba State, Northeast Brazil (Isoptera). Sociobiology 42(3):753760 .

Silva, E.G. \& Bandeira, A.G. 1999. Abundância e distribuição de cupins (Insecta, Isoptera) em solo de Mata Atlântica, João Pessoa, Paraíba. Rev. Bras. Biol. 13(1/2):13-36.

Souza, H.B.A., Alves, W.F. \& Vasconcellos, A. 2012. Termite assemblages in five semideciduous Atlantic Forest fragments in the northern coastland limit of the biome. Rev. Bras. Entomol. 56(1):67-72, http://dx.doi.org/10.1590/S0085-56262012005000013

Vasconcellos, A. 2010. Biomass and abundance of termites in three remnant areas of Atlantic Forest in northeastern Brazil. Rev. Bras. Entomol. 54(3):455-461, http://dx.doi.org/10.1590/S008556262010000300017

Vasconcellos, A., Bandeira, A.G., Almeida, W.O. \& Moura, F.M.S. 2008. Térmitas construtores de ninhos conspícuos em duas áreas de Mata Atlântica com diferentes níveis de perturbação antrópica. Neotrop. Entomol. 37:15-19, http://dx.doi.org/10.1590/S1519566X2008000100003

Vasconcellos, A., Bandeira, A.G., Moura, F.M.S., Araujo, V.F.P., Gusmão M.A.B. \& Constantino, R. 2010. Termite assemblages in three habitats under different disturbance regimes in the semi-arid Caatinga of NE Brazil. J. Arid Environ. 74:298-302, http:// dx.doi.org/10.1016/j.jaridenv.2009.07.007 
Ernesto M.V. et al.

Vasconcellos, A., Mélo, C.A.S., Segundo, E.M.V. \& Bandeira, A.G. 2005. Cupins de duas florestas de restinga do nordeste brasileiro. Iheringia, Zool. 95(2):127-131, http://dx.doi.org/10.1590/S007347212005000200003
Wood, T.G. \& Sands, W.A. 1978. The role of termites in ecosystems. In Production Ecology of Ants and Termites (M.V. Brian, ed.). Cambridge University Press, Cambridge, p.245-292.

Received 27/03/2014

Revised 14/05/2014

Accepted 04/09/2014 